\title{
Domestic sourcing by foreign-owned subsidiaries
}

\author{
David Williams \\ University of Liverpool Management School, University of Liverpool, Chatham Street, Liverpool \\ L69 7ZH, England; e-mail: d.williams@liv.ac.uk
}

\section{Frank McDonald}

Bradford School of Management, University of Bradford, Bradford BD9 4JL, England; e-mail: f.mcdonald@bradford.ac.uk

\section{Heinz J Tüselmann}

International Business Unit, Manchester Metropolitan University Business School, Aytoun Street, Manchester M1 3GH, England; e-mail: h.tuselman@mmu.ac.uk

\section{Colin Turner}

Hull University Business School, University of Hull, Hull HU6 7RX, England; e-mail: c.turner@hull.ac.uk

Received 1 June 2006; in revised form 13 November 2006; published online 7 November 2007

\begin{abstract}
This paper investigates the development of domestic sourcing by foreign-owned subsidiaries (FOS) in the UK. The regional development and international-business literatures are used to develop a conceptual framework on the links between autonomy, the use of networks, and domestic sourcing. Data from a survey of German, French, and US FOS in the UK is used to test the model. The results indicate that increased use of networks and increased operational decision-making autonomy are associated with increased domestic sourcing, but that only a minority of FOS are increasing their use of domestic sourcing. The growing importance of global sourcing is considered as a possible explanation for the low proportion of FOS that are increasing their use of domestic sourcing. The implications for regional-development policy of the findings are also assessed.
\end{abstract}

\section{Introduction}

The spillover benefits from foreign direct investment (FDI) have been identified as an important component in fostering industrial and regional development (Wren and Taylor, 1999; Young et al, 1994). One of the major spillover benefits from FDI is the development of domestic sourcing by foreign-owned subsidiaries (FOS). Domestic sourcing generates spillover benefits because the development of local supply chains by FOS leads to improvements in employment and the enhancement of technological and socioeconomic infrastructures. Given the importance attached to domestic sourcing by FOS it is not surprising that the determinants of, the obstacles to, and the effects of, domestic sourcing by FOS have been extensively examined (see, for example, Crone, 2002; Crone and Roper, 2001; Crone and Watts, 2002; 2003; Potter et al, 2003; Turok, 1997).

The regional-development literature has traditionally regarded the benefits from the international division of labour as the major rationale for FDI (Perrons, 1981; Phelps, 1993). Spatial aspects connected to ownership, internalisation, and location benefits have also been seen as driving FDI (Hill and Munday, 1992). Many FOS have been regarded as branch plants that are largely restricted to routine operations, because acquiring the benefits from the spatial distribution of labour and from other location-specific cost advantages are often thought to require FOS to have very limited autonomy from their parent multinational corporation (MNC) (Firn, 1975; Watts, 1981). The role of intracorporate competition has also been explored in the regional-development literature (Aksoy and Marshall, 1992; Phelps and Fuller, 2000). In this view, FOS compete within their corporations to obtain and enhance mandates 
that permit them to develop their activities. This literature is connected to the view that the granting of autonomy mandates enables subsidiaries to embed into their host locations in order to reap benefits from locally available resources. Therefore, the concept of embeddedness has become an important component in the investigation of the impact of FDI on host locations. The empirical evidence on embeddedness in the regional-development literature emphasises that the type and extent of embeddedness is important for domestic sourcing, but that links between embeddedness and domestic sourcing seems to be limited to a minority of FOS (Crone, 2002). This has been attributed to poor technological and socioeconomic infrastructures in host locations (Huggins, 2001; Potter et al, 2003; Turok, 1997) and to the low level of autonomy that afflicts many branch plants (Phelps, 1993; Watts, 1981).

The international-business literature that is centred on the impact of FDI on host locations is split into two main camps. A section of the literature investigates the spillover effects associated with FDI (Driffield and Mohd Noor, 1999; Driffield and Munday, 2000; Görg and Ruane, 2001). The empirical investigation of spillovers generally assumes that the motivation for FDI arises from ownership, location, and internalisation motives (Dunning, 1992). This literature has, in general, discovered positive but limited spillover benefits from domestic sourcing. Another section of the literature focuses on the implications for host locations of the strategic development of FOS (Hood and Taggart, 1997; McDonald et al, 2003; 2005; Tavares and Young, 2006; Williams, 2005). This literature is centred on autonomy mandates and the extent of the embeddedness of FOS in host locations. Empirical evidence has found that for many FOS the links between autonomy, embeddedness, and domestic sourcing are not strong. Moreover, significant relationships between these factors and domestic sourcing are usually restricted to a minority of FOS.

The location motive in the international-business literature is connected to the view of international division of labour in the regional-development literature, and there are some linkages between the ownership and internalisation motives and the branch-plant view. However, the main approaches used in the regional-development and international-business literatures have never been closely integrated. Both the strategic development of FOS in the international-business literature and the embeddedness and intracorporate approaches in the regional-development literature focus on the strategic orientation of MNCs in the context of the increasing competitive pressures that they face. Furthermore, both of these approaches are centred on the use of networks and the extent of autonomy given to FOS by their MNCs. There is, therefore, a strong connection between these literatures.

This paper connects these two literatures in order to investigate the importance of autonomy and embeddedness for domestic sourcing - in particular, to assess the extent of increasing domestic sourcing in the context of changes in autonomy and embeddedness in FOS. This type of approach has been advocated by researchers from both the regional development and the international-business fields of study as a useful way to expand our understanding of the effects of FDI on host locations (McCann and Mudambi, 2004). A conceptual framework is developed that is tested by a large-scale survey to investigate whether there are pronounced generic-autonomy and embeddedness factors involved in the use of domestic sourcing by FOS. This approach follows a similar approach (and uses the same dataset) that was used by some of the authors of this paper in a study on the strategic development of FOS and employment in host locations (McDonald et al, 2005). The paper begins with the development of a conceptual framework that is used to derive hypotheses on the links between changes in autonomy and the use of networks and change in domestic sourcing. The hypotheses are tested using a large-scale survey of French, German, and US 
manufacturing FOS in the UK. The findings are assessed in order to identify some of the major implications for regional-developed policy.

\section{Autonomy and use of local networks}

The development of domestic sourcing by FOS has a number of generic factors that seem to be associated with expanding local-supply chains. These can be summarised under to major headings;

1. The use of networks in the host location to enhance the ability to gather and process information and to gain access to desirable assets to improve the competitive edge available from using local-supply chains.

2. The autonomy to develop local-supply chains, which can be broken down into strategic decision-making autonomy, which permits FOS to create and develop local-supply chains, and operational decision-making autonomy, which allows for the effective utilisation of local-supply chains.

\section{Networks}

Economists, psychologists, and sociologists have delivered a large body of theory and evidence on the extent, character, and significance of networks for business operations. This work has been extensively applied to business and management studies, organisational studies, and economic geography. Attention has been focused on business networks, socioeconomic networks, the institutional underpinning of networks, and the importance of local, regional, national, and international networks (Andersson et al, 2002; Ivarsson, 2002; Phelps et al, 2003; Simmie and Sennett, 1999). This literature reveals that the importance of networks for business activities, particularly the proximity of network connections, is complex and multifaceted. This study, however, adopts a simple approach, based on the change in the use of local networks. This approach is used to test the view that the general development of local-network connections is important for the growth of domestic sourcing.

The importance of MNCs locating within local networks for enhancing competitiveness has been highlighted in work investigating the role of geographical factors in the internationalisation process (Dunning, 2000; Porter and Sölvell, 1998). This literature indicates that the use of local networks composed of other firms, R\&D agencies such as universities and government research bodies, local authorities, chambers of commerce, and other organisations can help FOS to attain their objectives (Andersson and Forsgren, 2000; Andersson et al, 2002; Crone and Roper, 2001; Crone and Watts, 2003; Phelps et al, 2003). These local networks increase the ability to benefit from collective learning and to realise innovation advantages that is associated with linkages to valuable sources of information and knowledge.

Local networks are at the core of industrial clusters that have been shown to deliver competitive advantages to FOS that locate in these geographical concentrations (Benito, 2000; Driffield and Munday, 2000; Enright, 2000). The literature on the use of local networks in industrial clusters has found evidence of extensive relationships between buyers, suppliers, and supporting agencies that is associated with enhanced quantity and quality of locally-provided products (Johannisson and Ramírez-Pasillas, 2002; Mackinnon et al, 2004). Increased use of networks should improve information gathering and processing, and enhance the capabilities of FOS to obtain desirable assets, this inducing a series of benefits that lead to increased use of domestic sourcing (see figure 1). These arguments lead us to the first hypothesis:

Hypothesis HI: Subsidiaries that increase their use of networks are positively associated with increased use of domestic sourcing. 


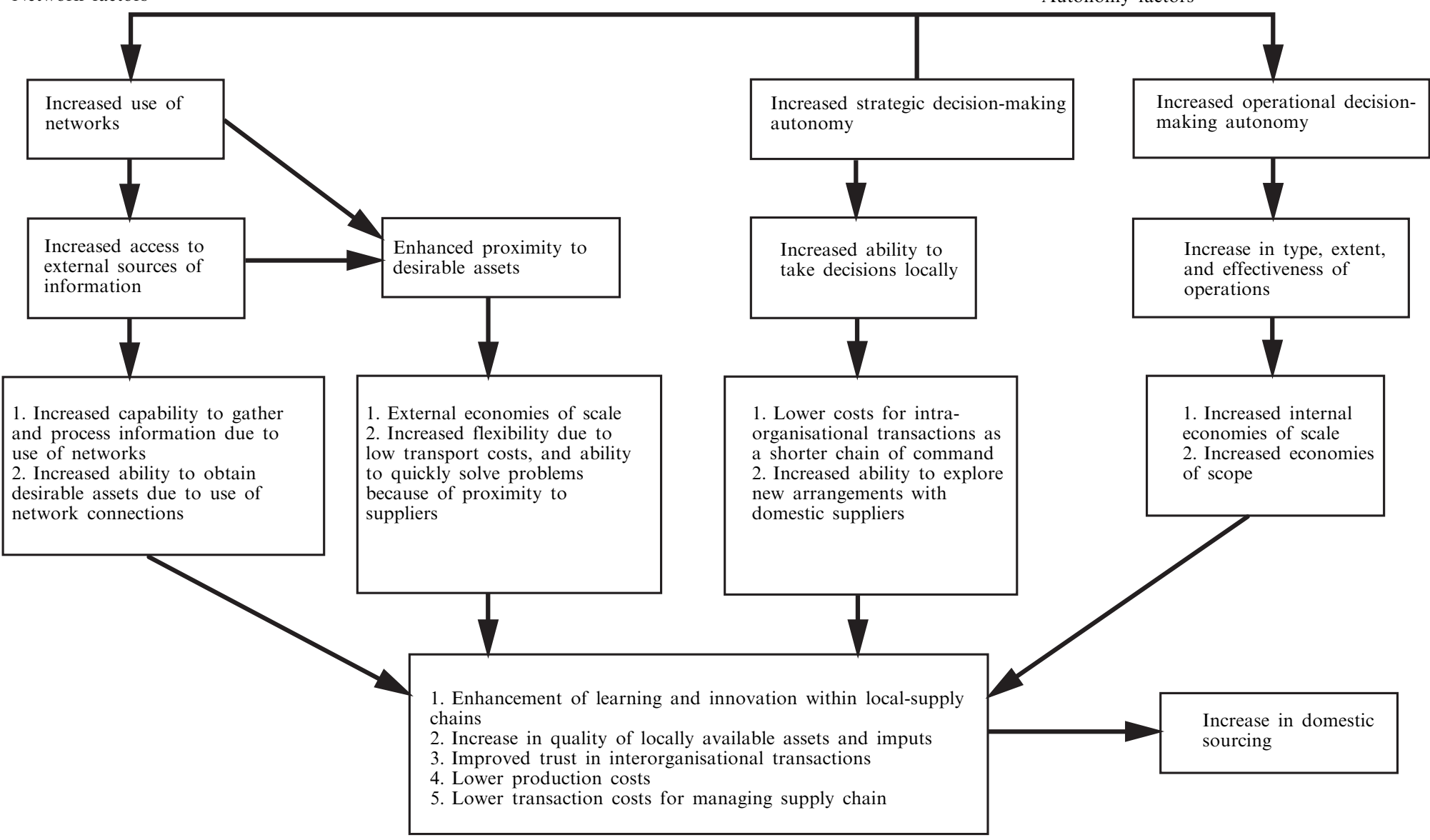

Figure 1. Foreign-owned subsidiaries and domestic sourcing. 


\section{Autonomy}

Autonomy is concerned with the extent to which a subsidiary has the right to make decisions with a degree of independence from headquarters (O'Donnell, 2000; Young and Taveres, 2004). Autonomy can be split into two main components: strategic decision-making autonomy and operational decision-making autonomy. Strategic decision-making autonomy is concerned with the ability to make major policy decisions in areas such as $\mathrm{R} \& \mathrm{D}$, production systems, product developments, and marketing. Operational decision-making autonomy is the ability to make tactical decisions on the type and scope of operations, such as decisions on the daily management of production, sales and distribution, and HR systems. The essential difference between strategic and operational decision making is that the former is connected to the power of FOS to make major policy decisions while the latter autonomy is connected to the freedom of FOS to make tactical decisions on operational matters.

\section{Strategic decision-making autonomy}

The development of strategic decision-making autonomy in host locations and the performance of FOS have been widely studied (Aksoy and Marshall, 1992; Andersson et al, 2002; Birkinshaw and Hood, 1998; Crone and Watts, 2002; Jarillo and Martinez, 1990; Phelps and Fuller, 2000; Tavares and Young, 2006). These studies find that good performance is related to granting FOS mandates to make decisions that foster the development and specialisation of subsidiaries. With a few exceptions (Perez and Sanchez, 2002; Tavares and Young, 2006; Williams, 2005), direct investigation of the role of strategic decision-making autonomy for the development of domestic sourcing has not been a preoccupation of the literature. However, positive relationships have been found between factors that are connected to strategic decision-making autonomy and the capacity to exploit locally available assets (Andersson and Forsgren, 2000; Birkinshaw and Hood, 1998; Pearce, 1999; Schmid and Schurig, 2003). This literature suggests that strategic decision-making autonomy leads to lower costs of conducting interorganisational transactions because of the shorter chain of command, the building up of trust between network partners, and the ability to innovate in relationships with domestic suppliers (see figure 1). This reasoning leads us to the second hypothesis:

Hypothesis H2: Subsidiaries that increase their strategic decision-making autonomy are positively associated with increased use of domestic sourcing.

\section{Operational autonomy}

A number of studies have found that mandates connected to operational decisionmaking autonomy have a positive effect on the performance of FOS (Hood and Taggart, 1997; Pearce, 1999). Such developments are common in the areas of innovation and R\&D activities (Cantwell and Iammarino, 2001; Tavares and Pearce, 2001). Increasing operational decision-making autonomy leads to learning associated with acquiring new technology and 'know how' from other parts of the MNC that can be used to improve the performance of FOS (Nohria and Ghoshal, 1997).

Zanfei (2000) argued that the greater the degree of operational decision-making autonomy the greater would be the development of linkages with local suppliers. Research indicates that FOS considered to be 'centres of excellence', with mandates to develop operational competencies, are more likely to develop domestic sourcing (Andersson and Forsgren, 2000; Dunning, 2000; Frost et al, 2002; Holm and Pedersen, 2000). Williams (2005) found that the development of supplier linkages by foreignowned firms in the UK economy was influenced by the development of operational decision-making autonomy. Granting mandates in operational decision-making autonomy permits FOS to reap economies of scale and economies of scope by using 
acquired 'know how' and locally available assets to better effect (see figure 1). This should lead to increased domestic sourcing. The third hypothesis reflects this view:

Hypothesis H3: Subsidiaries that increase their operational decision-making autonomy are positively associated with increased use of domestic sourcing.

\section{Combining autonomy and the use of networks}

The allocation of autonomy mandates by MNCs between the various subsidiaries often involves competition in terms of the availability of managerial resources within subsidiaries, the political influence of the subsidiary within the MNC, and the desirability of assets in host locations (Birkinshaw et al, 2004; Galunic and Eisenhardt, 1996; Maneu, 2003; Phelps and Fuller, 2000; Young and Tavares, 2004). This competition need not be centred on obtaining low-labour costs and other associated costs in a branch-plant-type relationship (Watts, 1981). Intracorporate competition can be associated with the building of centres of excellence in some subsidiaries (Holm and Pedersen, 2000). In these types of subsidiaries major operations are carried out, for the MNC as a whole or for large parts of the operations of the MNC. In these cases, labour and associated costs can be less important than access to desirable assets that are not available in other locations.

Subsidiaries that win the battle for increased autonomy should be able to develop local networks more effectively, as this should lead to lower transaction costs (due to increased trust and shorter chains of command) and an increased ability to explore new and innovative relationships with local suppliers. There is literature that suggests that there is a positive relationship between the granting of autonomy mandates and the use of networks (Andersson and Forsgren, 2000; Davis and Meyer, 2004; Holm et al, 2003; Phelps et al, 2003; White, 2004). Coordination benefits in managing the various factors involved in managing local-supply chains should also be available from combining the development of autonomy mandates and the use of local networks (Danese et al, 2005). Increased strategic decision-making autonomy should enable subsidiaries to develop new and innovative linkages with local suppliers, and increased operational decision-making autonomy should permit the development of networks that enhance the operational effectiveness of local-supply chains. This implies that there should be a chain of causation that runs from increased autonomy, which enables increased use of networks that subsequently leads to increased use of domestic sourcing. This outcome is shown in figure 1, where the direction of causation (shown by the bold lines) runs from increasing strategic and operational decision-making autonomy to increased use of networks, which in turn leads to increased use of domestic sourcing. This reasoning leads us to the final hypothesis:

Hypothesis H4: Subsidiaries that increase their autonomy mandates are associated with increased use of networks that in turn are linked to increased use of domestic sourcing.

\section{Methodology}

Data from a survey, conducted in 2002, of French, German, and US subsidiaries in the manufacturing sector in the UK was used to test the hypotheses (hypotheses 1-4, stated previously in this paper). In the period 1998-2002 these three countries accounted for $60 \%$ of the book value of manufacturing FDI stock in the UK (ONS, 2004). Questionnaires were sent to all known German and French subsidiaries, using the databases of the German-British Chamber of Commerce and Industry and the Anglo-Franco Chamber of Commerce and Industry. The sample for US subsidiaries was obtained from a stratified sample (based on region and industry) using the databases of the British-American Chamber of Commerce. A stratified sample had 
Table 1. Sample characteristics by industry and nationality (\%).

\begin{tabular}{lccc}
\hline Industry & German & French & US \\
\hline $\begin{array}{l}\text { Mechanical and electrical engineering } \\
\quad \text { surveyed }\end{array}$ & 61.7 & 41.0 & 39.0 \\
$\quad$ returned & 52.8 & 36.0 & 42.9 \\
$\begin{array}{l}\text { Automobiles } \\
\quad \text { surveyed }\end{array}$ & 12.6 & 12.0 & 7.4 \\
$\quad$ returned & 16.0 & 15.0 & 18.3 \\
$\begin{array}{l}\text { Chemical and pharmaceuticals } \\
\quad \text { surveyed }\end{array}$ & 13.7 & 11.5 & 24.1 \\
$\quad$ returned & 15.0 & 19.0 & 20.4 \\
$\begin{array}{l}\text { Others } \\
\quad \text { surveyed }\end{array}$ & 12.6 & 35.5 & 28.7 \\
$\quad$ returned & 13.5 & 30.0 & 18.4 \\
Total & & & 712 \\
$\quad$ surveyed & 623 & 593 & 98
\end{tabular}

Notes: Returned figures are usable responses; the percentage of industry surveyed was determined by the number of subsidiaries in those industries.

to be used because of the large number (over 10000) of US subsidiaries that are located in the UK. The questionnaire was piloted in twenty FOS of different nationalities, sizes, and industries and the feedback from the pilot tests were used to amend the questionnaire. The returns, after reminders, yielded 391 usable replies, which is a $20.3 \%$ response rate. A breakdown of the returns relative to proportion surveyed is provided in table 1.

Using the approach of Osterman (1994), nonresponse bias tests were conducted by means of logistic regression analysis to test for the probability of responses against nonrespondents across industrial sectors. Following the approach of Schmitt (2003), additional checks for nonresponse bias were conducted with the probability of response as the dependent variable and entry mode, industry, and establishment age as the independent variables. These tests revealed that the probability of response by the US subsidiaries that belong to vehicles and parts of the mechanical and electrical engineering industries was significantly different from FOS that belong to other manufacturing, and the probability of response by the French subsidiaries that belong to the chemicals and pharmaceutical industry was also significantly different from FOS that belong to other manufacturing. However, no significant difference in the probability of response by industry was found in the case of German subsidiaries. Following the approach of Malhotra and Birks (2003) weighting was used to account for nonresponse bias.

The composition of the questionnaire was guided by the approach used in previous studies of the activities of manufacturing subsidiaries (Holm and Pedersen, 2000; Holm et al, 2003; Taggart, 1996). Many studies (Andersson et al, 2002; Holm and Pedersen, 2000; Holm et al, 2003) make requests for sophisticated information on a large number of autonomy factors and the use of networks factors. The questionnaire did not, however, ask for self-assessment by respondents of the extent or importance of changes in autonomy and the use of networks, but simply asked if these factors had increased, decreased, or remained the same. This provides less information than asking for self-assessment on the importance of the changes, but reduces the likelihood that subsidiary managers report overoptimistic, or pessimistic, views on 
changes in these factors. The use of simple questions also made the questionnaire easy to complete, in terms of time and effort.

The approach taken in this study sacrificed richness of data in return for enhanced prospects of improving the validity of the responses, by minimising the risk of overestimation and underestimation, and obtaining a large number of observations, by restricting the amount of type of information that was sought from respondents. In this study we seek to investigate whether there are generic factors associated with domestic sourcing, and therefore whether the use of simple questions to identify generic factors is appropriate. In the light of the findings of this study, the benefits of using a richer data-gathering process is discussed in the findings and discussion section, and in the conclusion.

Table 2. Definitions and frequencies of the variables.

Variables

Measurement definition

$\%$ increased or

$\%$ in category

Dependent variable

Change in domestic sourcing

\section{Explanatory variables}

Change in strategic decision-making autonomy

Change in operational decision-making autonomy

Change in use of networks

\section{Control variables}

Technology

transfer

Age

Size

Nationality

Main activity of subsidiary

Entry mode

Industry
Increase in the proportion of domestic sourcing, or no increase in the proportion of domestic sourcing

Increase or no increase in strategic decision making connected to production and purchasing strategies

Increase or no increase in the operational decision-making autonomy connected to production and purchasing operations

Increase or no increase in use of networks - universities and R\&D agencies, supplier clubs, trade associations, and interfirm networks

Transfer or no transfer of technology to the subsidiary from the parent company

Subsidiary is up to ten years old, or more than ten years old

Subsidiary employs up to 100 employees, or more than 100 employees

Nationality of parent company (German, French, or US). US is used as the reference group

Subsidiary is principally engaged in manufacturing or sales and distribution

Greenfield, acquisition [mergers and acquisitions (M\&A)], or joint venture (JV). $\mathrm{JV}$ is used as the reference group

Type of industry:

mechanical and electrical engineering

automobile

chemicals

pharmaceuticals

others (reference group)
48.9 (technology transfer)

37.1 (up to

10 years)

69.1 (up to 100 employees)

German $=49.3$

French $=25.6$

$\mathrm{US}=25.1$

38.6 (mainly manufacturing)

Greenfield $=44.5$

$\mathrm{M} \& \mathrm{~A}=47.6$

$\mathrm{JV}=7.9$

39.1

16.6

14.0

4.4

25.9

Notes: Period of change is $1997-2002 ; n=391$. 
Probit and logit regression techniques are designed specifically for nominal data of the type available for this study (Long, 1997). Probit and logit regression estimates are not consistent in the presence of heteroscedasticity and omitted variables. Indeed, the effects of such problems are even more detrimental than they are in OLS models (Yatchew and Griliches, 1984). Thus, appropriate diagnostic tests for these problems, as well as for multicollinearity, were undertaken before the results were interpreted. The heteroscedasticity tests indicated that the variables 'French nationality' and 'pharmaceutical industry' disturbed the requirement of a constant variance of the model's error terms. Thus a heteroscedastic probit regression model was used to test hypotheses $\mathrm{H} 1, \mathrm{H} 2$, and $\mathrm{H} 3$. The square of the predicted value was included in the model, with a resulting estimate being nonsignificant, indicating that the model is not likely to have any omitted variables. The STATA software automatically deals with problems of multicollinearity by omitting independent variables that cause unacceptable levels of multicollinearity (Long and Freese, 2003).

The dependent variable was measured by a binary system of either an increase in proportion of domestic sourcing or no increase in the proportion of domestic sourcing. The explanatory variables (change in networks, decision-making autonomy, and operational autonomy) were measured by a binary system of either an increase in or no increase in areas connected to production and purchasing. The definitions and the measurement of the dependent, explanatory, and control variables are shown in table 2 .

Probit regression models cannot be used to assess the interaction between the autonomy and use of networks variables and increased use of domestic sourcing. Moreover, the nominal data used in this study are not amenable to the use of techniques such as structural-equation modelling to test the interaction between the autonomy and use of networks variables and domestic sourcing. Hierarchical log-linear modelling, which can use nominal data, was therefore used to test hypothesis $\mathrm{H} 4$. The model begins by considering interaction between all of the variables, that is, with three-way interactions between the four variables-strategic and operational decision-making autonomy, the use of networks, and domestic sourcing. This is the saturated model (Christensen, 1997). The modelling process deletes higher order interaction terms until it finds the smallest number of interactions between the four variables that provide at least as good a model (the parsimonious model) as the saturated model. In addition, the results reveal any combination of autonomy and use of networks variables that are significantly related to increased use of domestic sourcing in any particular model (Knoke and Burke, 1980).

\section{Findings and discussion}

The proportion of FOS that have increased their share of domestic sourcing is less than a quarter, and less than a third of FOS have increased use of networks and strategic decision-making autonomy. Only operational decision-making autonomy has experienced a substantial increase (see table 2). These findings confirm those of other studies that suggest that only a small minority of FOS are developing domestic sourcing (Phelps et al, 2003; Potter et al, 2003; Williams, 2005). The small proportion of FOS in the manufacturing sector whose main business is manufacturing $(38.6 \%)$ also indicates that supplying the UK market by sales and distribution operations is the major activity of many FOS in the manufacturing sector. Nearly $63 \%$ of FOS are more than ten years old, about $69 \%$ have 100 or fewer employees, and nearly $48 \%$ of FOS originates from mergers and acquisitions (M\&A). The characteristics of the sample suggest that most FOS in the manufacturing sector are small, old, originate from M\&A, and are mainly involved with sales and distribution. 
Table 3. Regional distribution of key variables ( $\%$ increase).

\begin{tabular}{|c|c|c|c|c|}
\hline & North $^{\mathrm{a}}$ & South $^{\mathrm{b}}$ & East $^{\mathrm{c}}$ & West $^{\mathrm{d}}$ \\
\hline Change in domestic sourcing & 14.6 & 32.6 & 20.2 & 32.6 \\
\hline $\begin{array}{l}\text { Change in strategic decision-making } \\
\text { autonomy }\end{array}$ & 16.8 & 31.1 & 21.0 & 31.1 \\
\hline $\begin{array}{l}\text { Change in operational decision-makimg } \\
\text { autonomy }\end{array}$ & 17.2 & 37.2 & 20.5 & 25.1 \\
\hline Change in use of networks & 24.5 & 29.1 & 23.6 & 22.7 \\
\hline
\end{tabular}

The regional distribution of key characteristics of FOS is shown in table 3. The official UK regions classification was collapsed into four regions because of the low number of observations in some of the regions. The most obvious regional difference is that FOS in the North have lower incidences of increases in domestic sourcing, and strategic and operational decision-making autonomy. The South and West have the largest increases in these areas. The South shows the strongest increases in these factors. Increased use of networks is similar across all four regions. The results on regional distributions in this study support the findings from studies that used more disaggregated regions (for example, Potter et al, 2003). Inserting the four aggregated regions into the regression model as a control variable did not improve the predictive power of the model, and none of the regions had a significant coefficient. A larger

Table 4. UK sourcing model: heteroscedastic probit model.

\begin{tabular}{|c|c|c|c|c|}
\hline & Coefficient & Standard error & $z$ & $p>z$ \\
\hline \multicolumn{5}{|l|}{ Explanatory variables } \\
\hline $\begin{array}{l}\text { Change in strategic decision- } \\
\text { making autonomy }\end{array}$ & 0.260 & 0.185 & 1.38 & 0.167 \\
\hline $\begin{array}{l}\text { Change in operational decision- } \\
\text { making autonomy }\end{array}$ & 0.219 & 0.111 & 1.97 & $0.049^{* *}$ \\
\hline Change in use of networks & 0.240 & 0.114 & 2.10 & $0.035^{* *}$ \\
\hline \multicolumn{5}{|l|}{ Control variables } \\
\hline Technology transfer & 0.264 & 0.150 & 1.75 & $0.079 *$ \\
\hline Age & 0.042 & 0.111 & 0.38 & 0.708 \\
\hline Size & -0.041 & 0.119 & -0.34 & 0.732 \\
\hline German nationality & 1.065 & 0.943 & 1.13 & 0.259 \\
\hline French nationality & 2.949 & 2.048 & 1.44 & 0.150 \\
\hline Main activity of subsidiary & -0.134 & 0.120 & -1.11 & 0.265 \\
\hline Greenfield & 0.041 & 0.152 & 0.27 & 0.788 \\
\hline Merger and acquisition & 0.129 & 0.253 & 0.51 & 0.611 \\
\hline $\begin{array}{l}\text { Mechanical and electrical } \\
\text { engineering }\end{array}$ & 0.253 & 0.196 & 1.29 & 0.196 \\
\hline Automobile & -0.240 & 0.182 & -1.32 & 0.187 \\
\hline Chemicals & -0.108 & 0.181 & -0.59 & 0.553 \\
\hline Pharmaceutical & 0.595 & 0.378 & 1.57 & 0.116 \\
\hline Constant & -1.811 & 0.565 & -3.20 & 0.001 \\
\hline
\end{tabular}

Notes: $\mathrm{n}=391 ; \log$ likelihood $=-187.3293$; Probability $>\chi^{2}=0.0000$; Pseudo $R^{2}=0.1071$; *significant at $10 \%$; * significant at $5 \%$; a significant and positive coefficient indicates that increases in explanatory and control variables are likely to be associated with an increased share of domestic sourcing. 
sample, using richer data, and which utilises disaggregated regions, is required to assess more fully the importance of the regional distribution of FOS in terms of autonomy, use of networks, and domestic sourcing.

Increased use of networks is significantly and positively related to increases in domestic sourcing indicating support for hypothesis H1 (see table 4). This finding reinforces the studies that link the use of networks to enhanced use of domestic sourcing (Davis and Meyer, 2004; Pearce, 1999; White, 2004). However, the small numbers of FOS that have increased their use of networks indicates that this positive effect is limited to a minority of cases. This could be associated with problems encountered by FOS in finding appropriate partners to develop local-supply chains (Crone and Watts, 2003; Potter et al, 2003) and the growing importance of global sourcing (see below).

There is no support for hypothesis $\mathrm{H} 2$ because increase in strategic decision-making autonomy is not significantly related to the increased use of domestic sourcing. The regional-development literature has identified a branch-plant syndrome that leads to restricted autonomy, that in turn limits the development of local-supply chains (Firn, 1975; Phelps, 1993; Watts, 1981). However, this study found no evidence that increased strategic decision-making autonomy is associated with increased domestic sourcing. It is possible that strategic decision-making autonomy mandates in many FOS do not significantly extend to policies on sourcing, perhaps because many MNCs are increasingly developing global sourcing (Yip, 2003). A study by Tavares and Young (2006) highlights that many FOS appear to be focusing increasingly on developing global-supply sourcing, even in those FOS with high levels of autonomy.

Operational decision making is significantly associated with increases in domestic sourcing, providing support for hypothesis H3. This finding supports other studies that have found links between operational autonomy and the development of domestic sourcing (Hood and Taggart, 1997; Pearce, 1999). Developing operational decisionmaking autonomy in purchasing and manufacturing operations has also been found to be important to make best use of local-supply chains (Andersen and Rask, 2003). Operational decision-making autonomy is the only explanatory variable to have experienced substantial increases, indicating that operational decision-making autonomy is likely to be the most important factor linked to increasing domestic sourcing. Although about $60 \%$ of FOS increased operational decision-making autonomy, only $23 \%$ of FOS increased domestic sourcing by more than the average increase (see table 2). This implies that, in many cases, increasing operational decision-making autonomy in areas connected to purchasing and production may be connected to developing global rather than domestic sourcing (Gereffi and Kaplinsky, 2001; Quintens et al, 2005; Tavares and Young, 2006; Yip, 2003).

The results of the log-linear modelling tests revealed that there are no significant relationships between any of the autonomy variables and increased use of networks. Furthermore, no parsimonious model could be found that has at least as good a fit as the saturated model. There is, therefore, no support for hypothesis H4. The failure to find significant relationships between autonomy and use of networks, and subsequently to domestic sourcing indicates that there are no significant interactions between any of the possible combinations of autonomy and the use of networks and the development of local supply chains. These types of interactions have been identified in some studies (Holm et al, 2003; Ivarsson, 2002). This study suggests however that there is no clear case to be made for combinations of autonomy and the use of networks as a generic means to promote local-supply chains. Combinations of strategic and operational decision-making autonomy and the use of local networks may be associated with developing local-supply chains in some cases (for example, large assembly plants). A larger and richer data-gathering process together with more sophisticated testing 
techniques is probably necessary in order to identify possible linkages between increased autonomy and use of networks, and any subsequent increase in domestic sourcing.

This result may also be explained by the growing use of global rather than domestic sourcing. Given the advantages that FOS have to develop global sourcing, they are likely to be at the vanguard of developing global sourcing (Yip, 2003). Therefore, many FOS may use strategic and operational decision-making autonomy and use networks to develop global sourcing. This type of behaviour was found in a study by Tavares and Young (2006), where FOS with strong high-product mandates (implying high levels of autonomy in production decision) had a strong association with global sourcing. Therefore, even in FOS that have increased strategic and operational decision making, the chain of causation may run from increased autonomy to increased use of networks, which subsequently leads to the development of global sourcing.

\section{Some implications for regional development policy}

The results of this study reveal that less than $25 \%$ of FOS are increasing their proportion of domestic sourcing. The virtuous development of the use of networks and autonomy factors to promote growth in the share of domestic sourcing (outlined in figure 1) only seems to work for about $25 \%$ of subsidiaries. Moreover, increases in strategic autonomy do not appear to be important for increasing domestic sourcing. Indeed, there is evidence (Tavares and Young, 2006) that FOS with strong product mandates are more likely to develop global sourcing. There is no support for the view that increases in strategic and operational decision-making autonomy factors leads to increased use of networks with subsequent enhanced use of domestic sourcing. For those FOS that are increasing their use of domestic sourcing, operational decision making autonomy and use of networks is important, but there is no evidence that there is a direct relationship between operational autonomy and use of networks that leads to a greater use of domestic sourcing.

That only a small proportion of FOS are experiencing above average increases in domestic sourcing may be partly explained by the large number of subsidiaries that are old, became FOS via M\&A, and that are mainly engaged in sales and distribution. Many FOS with these characteristics are unlikely to be capable of extensive development of their local-supply chains. Moreover, may FOS may be limited by a branch-plant syndrome (Phelps, 1993; Watts, 1981) combined with (and linked to) poor institutional frameworks in host locations, and resources bases that lack the type of assets that are desirable given the strategic objectives of MNCs (Crone, 2002; Potter et al, 2003). There is a low likelihood that such FOS will make important contributions to regional-development objectives such as improvements in employment, and enhancing technological and socioeconomic infrastructures. In regions with high proportions of such FOS, policies need to be based on developing regions so that they can attract FOS that are more dynamic and focused in high-value-added areas that are expanding in high-labour-cost countries such as the UK. This is linked to the problematic issue of what are the major determinants of regional competitiveness in business environments that are becoming increasingly international, and how, in these circumstances, policies can be devised and implemented that encourage the development of regional competitiveness (Kitson et al, 2004).

These findings case doubt about the wisdom of the widespread use of regionaldevelopment strategies that are focused on developing autonomy in FOS, in combination with the use of local networks to boost the proportion of domestic sourcing. These types of approach have been advocated as a means to achieve regional-development objectives by boosting the spillover effects available from developing local-supply chains (Crone and Roper, 2001; Huggins, 2001; Phelps et al, 2003; Potter et al, 2003; White, 2004). 
The results from this study, however, provide no support for the adoption of this type of regional-development approach as a generic policy to maximise domestic-sourcing benefits. To identify and enable FOS that fall into the category of those that develop their local-supply chains may require company-specific rather than generic regionaldevelopment policy approaches (Tavares and Young, 2006). Such company-specific approaches need to encompass the overall strategic objectives of MNCs, and in particular the trends towards global sourcing. However, developing company-specific approaches may lead to policy makers becoming entangled in intra-MNC and interMNC manoeuvres over the expansion and curtailment of the activities of FOS. This could lead to the capture of policy makers by MNCs, with consequent harmful effects such as interregional grant and subsidy escalation, and wasteful expenditures to attract and retain FDI (Phelps, 2000; Phelps and Fuller, 2000). Company-specific policy approaches clearly require careful formulation and implementation if these problems are to be avoided (McDonald et al, 2005).

The growth of global sourcing is likely to increase incentives to develop not only local networks but also national and international networks, to enable FOS to take advantage of the opportunities presented by global sourcing. International networks have been identified as being of growing importance for regional competitiveness, particularly for the development of business activities connected to gathering and processing information and knowledge (Simmie, 2003; Simmie and Sennett, 1999; Torre and Rallet, 2005). In this context, undue policy focus on promoting material-input linkages may not be sensible, because FOS that are likely to be dynamic and fast growing in high-labour-cost countries are more likely to be engaged primarily in information and knowledge gathering, and innovation activities. In a world where global sourcing of material inputs is becoming more important, countries with relatively high labour costs should focus on developing domestic sourcing that is based on gathering information and knowledge, and transforming this into innovations that are useful for promoting the strategies of MNCs (Tavares and Young, 2006). Policies of this type may hasten the run down of lower value-added domestic sourcing, but would help to enhance the supply of inputs to FOS that are firmly based in competitive advantages not available in overseas locations (McDonald et al, 2005).

Helping FOS faced with pressures to develop knowledge-based sourcing by connecting 'regional buzz' (Bathelt et al, 2002; Storper and Venables, 2002) in their host locations to national and international networks is likely to be more important than developing local networks to enhance material-inputs sourcing. Developments in research in regional-development policy have already led to an acknowledgement of the importance of information, knowledge, and innovation. However, this is often linked to an end product of enhancing local material-input supply. But, for many FOS the end product of embeddedness in host regions, gained from developing autonomy and the use of networks, is likely to be information, knowledge, and innovation inputs that have little or no material-input implications in host locations. In this case the important local inputs are labour with high skills in gathering information, and knowledge to develop innovations in areas such as $\mathrm{R} \& \mathrm{D}$, new products, product and production development, and market intelligence. Labour in FOS with these functions are also likely to need to be entrepreneurial in order to initiate developments and to be able to sell their ideas and proposals to other parts of their MNC. Entrepreneurship of this type will require interorganisational and intraorganisational relationships in the host location and with other locations, that can effectively exploit the skills of the labour force to transfer information, knowledge, and innovation to the various parts of MNCs (Birkinshaw et al, 2004). It is not clear if our current research approaches and data gathering have adapted to this type of end product. 


\section{Conclusion}

This study has shown that there is no simple relationship between increases in subsidiary autonomy, the use of local networks, and the development of domestic sourcing. The type of virtuous development of local-supply chains outlined in figure 1 seems to apply only in a minority of cases. Moreover, the development of strategic decision-making autonomy in FOS does not seem to be important for the development of domestic sourcing. Where local-supply chains are being developed, the role of local networks is important. Therefore, this study provides further support for the view that effective local-supply chain development will be fostered through building relationships by means of local networking. However, this study found that relatively few FOS had increased their use of networks. Increases in local-sourcing activities are also associated with increases in operational decision-making autonomy. Although the majority of FOS are increasing operational decision-making autonomy, this does not transfer to large numbers of subsidiaries increasing domestic sourcing. It is likely that this is because many FOS are increasing operational decision-making autonomy in production and purchasing to help them to develop global sourcing.

The findings have significant implications for the conduct of regional-development policies that are intended to encourage FOS capabilities and the use of networking to enhance the use of local procurement. The study suggests that there are unlikely to be large spillover effects from FDI connected to the development of local-supply chains. Moreover, the growing use by MNCs of global sourcing is likely to further reduce these spillover effects. Regional-development policies that seek to maximise the spillover benefits from the development of local-supply chains need to incorporate the strategic objectives of MNCs into the identification of policies that are likely to encourage domestic sourcing. In this respect, the growing importance of global sourcing of material inputs is clearly an important factor. The implication of this is that-in high-labour-cost countries - less attention should be paid to developing material inputs sourcing and more attention should be paid to enhancing the effectiveness of host locations to supply information, knowledge, and innovation.

Further research is required to help to identify the type of FOS that are likely to develop domestic sourcing, and to explore the type and extent of autonomy and use of networks factors that are associated with the enhancement of local supply chains. This research needs to explicitly consider the influence of the strategic objectives of MNCs, particularly the growing use of global sourcing. Such research needs to be integrated into research on the determinants of regional competitiveness. This requires the development of conceptual models that integrate the relevant research from international business (on autonomy and embeddedness) with that from regional development (on embeddedness, regional buzz, and regional competitiveness). The resultant conceptual models need to be tested by rich and extensive data gathering, that accurately measures the key variables of autonomy and embeddedness in the context of the strategic objectives of MNCs, and also measures the determinants of regional competitiveness in business environments that are becoming increasingly international.

\section{References}

Aksoy A, Marshall J, 1992, "The changing corporate head office and its spatial implications" Regional Studies 26149 - 162

Andersen P, Rask M, 2003, "Supply chain management: new organisational practices for changing procurement realities" Journal of Purchasing and Supply Management 983 -95

Andersson U, Forsgren M, 2000, "In search of centres of excellence: network embeddedness and subsidiary roles in multinational corporations" Management International Review 40329 - 350

Andersson U, Forsgren M, Holm U, 2002, "The strategic impact of external networks: subsidiary performance and competence development in the multinational corporation" Strategic 
Bathelt H, Malberg A, Maskell P, 2002, "Clusters and knowledge: local buzz, global pipelines and the process of knowledge creation”, WP 02-12, Danish Research Unit For Industrial Dynamics, Aalborg

Benito G, 2000, "Industrial clusters and foreign companies' centres of excellence in Norway", in The Emergence and Impact of MNC Centres of Excellence: A Subsidiary Perspective Eds U Holm, T Pedersen (Macmillan, Basingtoke, Hants) pp $97-112$

Birkinshaw J, Hood N, 1998 Multinational Corporate Evolution and Subsidiary Development (Macmillan, Basingstoke, Hants)

Birkinshaw J, Hood N, Young S, 2004, "Subsidiary entrepreneurship, internal and external competitive forces, and subsidiary performance" International Business Review 14227 - 248

Cantwell J, Iammarino S, 2001, "EU regions and multinational corporations: change, stability and strengthening of technological comparative advantages" Industrial and Corporate Change 10 $1007-1037$

Christensen R, 1997 Log-Linear Models and Logistic Regression (Springer, New York)

Crone M, 2002, "Local sourcing by multinational enterprise plants: evidence from the UK regions and the implications for policy" Environment and Planning C: Government and Policy 20 $131-149$

Crone M, Roper S, 2001, "Local learning from multinational plants: knowledge transfers in the supply chain" Regional Studies $35535-548$

Crone M, Watts H, 2002, "Stability and change in the supply chains of multinational plants: the managerial voice" Tijdschrift voor Economische en Sociale Geografie 93277 - 288

Crone M, Watts H, 2003, "The determinants of regional sourcing by multinational manufacturing firms: evidence from Yorkshire and Humberside, UK" European Planning Studies 11 717 - 737

Danese P, Romano P, Vinelli A, 2005, "Managing business practices across supply networks: the role of coordination mechanism" Journal of Purchasing and Supply Management 10 165-177

Davis L, Meyer K, 2004, "Subsidiary research and development, and the local environment" International Business Review 13359 - 382

Driffield N, Mohd Noor A, 1999, "Foreign direct investment and local input linkages in Malaysia" Transnational Corporations $81-24$

Driffield N, Munday M, 2000, "Industrial performance, agglomeration, and foreign manufacturing investment in the UK" Journal of International Business Studies 3121 - 37

Dunning J, 1992, "The competitive advantage of nations and the activities of transnational corporations" Transnational Corporations 1 135-168

Dunning J, 2000, "Regions, globalization, and the knowledge economy: the issues stated", in Regions, Globalization, and the Knowledge Economy Ed. J H Dunning (Oxford University Press, Oxford) pp $1-29$

Enright M, 2000, "Globalization of competition and the localization of competitive advantage: policies towards regional clustering", in Globalization of Multinational Enterprise Activity and Economic Development Eds N Hood, S Young (Palgrave Macmillan, Basingstoke, Hants) pp $303-331$

Firn J, 1975, "External control and regional development: the case of Scotland" Environment and Planning A $7393-414$

Frost T, Birkinshaw H, Ensign P, 2002, "Centers of Excellence in Multinational Corporations" Strategic Management Journal $23997-1018$

Galunic D, Eisenhardt K, 1996, "The evolution of intracorporate domains: divisional charter losses in high-technology multidivisional corporations" Organization Science 7255 -282

Gereffi G, Kaplinsky R, 2001, "The value of value chains" IDS Bulletin 32 1-136

Görg H, Ruane F, 2-1, "Multinational companies and linkages: panel data evidence for the electronics sector" International Journal of the Economics of Business 81 - 18

Hill S, Munday M, 1992, "The UK Regional Distribution of Foreign Direct Investment: Analysis and Determinants" Regional Studies 26535 - 544

Holm U, Pedersen T, 2000 The Emergence and Impact of MNC Centres of Excellence: A Subsidiary Perspective (Macmillan, Basingstoke, Hants)

Holm U, Malmberg A, Sölvell O, 2003, "Subsidiary impact on host-country economies - the case of foreign-owned subsidiaries attracting investment into Sweden" Journal of Economic Geography 3 $389-408$

Hood N, Taggart J, 1997, "German foreign direct investment in the UK and Ireland: survey evidence" Regional Studies 31 139-150

Huggins R, 2001, "Embedding inward investment through workforce development: experiences in Wales" Environment and Planning C: Government and Policy 19833 - 848 
Ivarsson I, 2002, “Transnational corporations and the geographical transfer of localised technology: a multi-industry study of foreign affiliates in Sweden” Journal of Economic Geography $221-243$

Jarillo C, Martinez J, 1990, "Different roles for subsidiaries: the case of multinational corporations in Spain" Strategic Management Journal $11501-512$

Johannisson B, Ramírez-Pasillas M, 2002, "The institutional embeddedness of local inter-firm networks: a leverage for business creation" Entrepreneurship and Regional Development 14 $297-315$

Kitson M, Martin R, Tyler P, 2004, "Regional competitiveness: an elusive yet key concept” Regional Studies 38991 - 999

Knoke D, Burke P, 1980 Log-linear models (Sage, London)

Long J, 1997 Regression Models for Categorical and Limited Dependent Variables (Sage, London)

Long J, Freese J, 2003 Regression Models for Categorical Dependent Variables Using STATA (STATA Press, College Station, Texas)

McCann P, Mudambi R, 2004, "The location behaviour of the multinational enterprise: some analytical issues" Growth and Change 35491 - 524

McDonald F, Tüselmann H, Heise A, Williams D, 2003, "Employment in host regions and foreign direct investment" Environment and Planning C: Government and Policy 21 687-701

McDonald F, Tüselmann H J, Voronkova S, Dimitratos P, 2005, "The strategic development of foreign owned subsidiaries and direct employment in host locations in the United Kingdom" Environment and Planning C: Government and Policy 23 867-882

Mackinnon D, Chapman K, Cumbers A, 2004, "Networking, trust and embeddedness among SMEs in the Aberdeen oil complex" Entrepreneurship and Regional Development 16 87-106

Malhotra N, Birks D, 2003 Marketing Research: Applied Approach (Prentice-Hall, London)

Maneu I, 2003, "The managerial network in a multinational enterprise and the resource profile of subsidiaries" Journal of International Management 9133 - 151

Nohria N, Ghoshal S, 1997 The Differentiated Network: Organizing Multinational Corporations for Value Creation (Jossey-Bass, San Francisco, CA)

O'Donnell S, 2000, "Managing foreign subsidiaries: agents of headquarters or an independent network?" Strategic Management Journal 21525 - 548

ONS, 2004 UK Balance of Payments Office for National Statistics, Cardiff

Osterman P, 1994, "How common is workplace transformation and who adopts it?" Industrial and Labor Relations Review 47173 - 188

Pearce R, 1999, "The evolution of technology in multinational enterprises: the role of creative subsidiaries" International Business Review 8125 - 148

Perez M, Sanchez A, 2002, "Lean production and technology networks in the Spanish automotive supplier industry" Management International Review 42261 - 278

Perrons D, 1981, "The role of Ireland in the new international division of labour: a proposed framework for regional analysis" Regional Studies 1581 - 100

Phelps N, 1993, "Branch plants and the evolving spatial division of labour: a study of material linkage change in the northern region of England" Regional Studies 27 87-101

Phelps N, 2000, "The locally embedded multinational and institutional capture" Area 32 169-178

Phelps N, Fuller C, 2000, "Multinationals, intracorporate competition and regional development" Economic Geography $76224-243$

Phelps N, Mackinnon D, Stone I, Braidford P, 2003, "Embedding the multinationals?: institutions and the development of overseas manufacturing affiliates in Wales and north east England" Regional Studies $3727-40$

Porter M, Sölvell O, 1998, "The role of geography in the process of innovation and the sustainable competitive advantage of firms", in The Dynamic Firm: The Role of Technology, Strategy, and Regions Eds A Chandler, P Hagstrom, O Sölvell (Oxford University Press, Oxford) pp 45-63

Potter J, Moore B, Spires R, 2003, "Foreign manufacturing investment in the United Kingdom and the upgrading of supplier practices" Regional Studies 37 41-60

Quintens L, Matthyssens P, Faes W, 2005, "Purchasing internationalisation on both sides of the Atlantic" Journal of Purchasing and Supply Management $1157-71$

Schmid S, Schurig A, 2003, "The development of critical capabilities in foreign subsidiaries: disentangling the role of the subsidiary's business" International Business Review 12755 - 782

Schmitt M, 2003, "Deregulation of the German industrial relations system via foreign and direct investment: are subsidiaries of Anglo-Saxon MNCs a threat for the institutions of industrial democracy in Germany?" Economic and Industrial Democracy 24349 - 377

Simmie J, 2003, "Innovation and urban regions as national and international nodes for the transfer and sharing of knowledge" Regional Studies $37607-620$ 
Simmie J, Sennett J, 1999, “Innovative clusters: global or local linkages” National Institute Economic Review $17087-99$

Storper M, Venables A, 2004, "Buzz: face-to-face contact and the urban economy" Journal of Economic Geography 4351 - 370

Taggart J, 1996, "Autonomy and procedural justice: a framework for evaluating subsidiary strategy" Journal of International Business Strategy 28 51 - 76

Tavares A, Pearce R, 2001, "European integration and structural change in the multinational: evidence from foreign subsidiaries operating in Portugal", in International Business:

European Dimensions Eds M Hughes, J Taggart (Palgrave, Basingstoke, Hants) pp 123-137

Tavares A, Young S, 2006, "Sourcing patterns of foreign-owned multinational subsidiaries in Europe" Regional Studies 40583 - 599

Torre A, Rallet A, 2005, "Proximity and localization" Regional Studies 39 47-59

Turok I, 1997, "Linkages in the Scottish electronics industry: further evidence" Regional Studies $31705-711$

Watts H, 1981 The Branch Plant Economy (Longman, Harlow, Essex)

White M, 2004, "Inward investment, firm embeddedness and place: an assessment of Ireland's multinational software sector" European Urban and Regional Studies $11243-260$

Williams D, 2005, "Supplier linkages of foreign-owned manufacturing firms in the UK: the influence of entry mode, subsidiary autonomy and nationality" European Planning Studies 1373 - 91

Wren C, Taylor J, 1999, "Industrial restructuring and regional policy" Oxford Economic Papers $51487-516$

Yatchew A, Griliches Z, 1984, "Specification error in probit models" Review of Economics and Statistics $66134-139$

Yip G, 2003 Total Global Strategy (Prentice-Hall, Upper Saddle River, NY)

Young S, Tavares A, 2004, "Centralization and autonomy: back to the future" International Business Review 13 215-237

Young S, Hood N, Peters E, 1994, "Multinational enterprises and regional economic development" Regional Studies 28 657-677

Zanfei A, 2000, "Transnational firms and the changing organisation of innovative activities" Cambridge Journal of Economics 24515 - 542 
Conditions of use. This article may be downloaded from the E\&P website for personal research by members of subscribing organisations. This PDF may not be placed on any website (or other online distribution system) without permission of the publisher. 